\title{
Apartheid and Resistance in South Africa 1948-1969
}

\author{
Boualem Belkacemi \\ Yusuf Al-Ghailani \\ Sultan Qaboos University, Sultanate of Oman
}

\begin{abstract}
The paper discusses the historical establishment of the apartheid system in South Africa since 1948 and the resistance struggle of Africans against its racial policies until the year 1969. The first part of the paper deals with the origins of white domination in South Africa, going back to mid-seventeenth century with the Dutch aggression against African tribes all the way through to the twentieth century and the appearance of the main political parties behind the ideology of apartheid. The second part of the paper focuses on the internal opposition to the segregationist state created by the whites in South Africa. Opponents came from different circles: intellectuals, politicians, churchmen, civil servants, lawyers, doctors, etc. But the most prominent opponent of Apartheid was the Africa National Congress (ANC) which was founded in 1912. The third and final part analyses the international struggle against apartheid in the United Nations forums. This opposition took first the form of political and diplomatic actions against the racial system of South Africa, and then was materialized by economic sanctions which revealed to be the most susceptible to affect seriously the apartheid regime.
\end{abstract}

Keywords: apartheid, South Africa, resistance, ANC, United Nations

\section{Introduction}

The independence of the African countries announced the end of the colonial era either through armed revolts or political negotiations. The only exception to this rule was South Africa where the kind of colonisation that existed is known as the "domestic colonization". The country's wealth and government control had been for a long time in the hands of a minority of whites who established a racist and rigid system of rulet over the other ethnic groups, mainly the Africans and the Indians. Thus, South Africa moved gradually to the establishment of a totalitarian state where racial discrimination reached massive proportions. Opposition to Apartheid started with South African non-white activists and even some whites, who played an important role in convincing the international community to incriminate the racist regime, which reacted politically and economically by putting more pressure and oppression on the non-white ethnic groups. The purpose of this article is to shed light on the origins of the apartheid system and the opposition that arose against its policies in South Africa and in the world, mainly through the United Nations.

\section{Apartheid in South Africa, 1948-1969: Origins of Domination}

Early contacts between the Europeans and the Sub-Saharan Africans were based on trade. Pushed by a strong sense of mercantilism, the first European traders established commercial relations with Africans on the grounds of mere interests. However, the presence of the Europeans in South Africa was primarily for settlement and not for commercial interests. Thus, land was a cause of disagreement between the newcomers, mainly the 
Dutch who set foot in the country in 1652, and the natives. Two major tribes represented the latter: the Khoi and the San who were, respectively, herdsmen and hunters. In order to take the land from its owners, the Dutch waged wars against indigenous inhabitants. The balance of power tilted in favour of the Dutch since they used far more sophisticated and efficient weaponry.

The Dutch settlers regarded the natives as inferior race that had no natural rights to rise against them. Their religious convictions and beliefs were strongly influenced by John Calvin's ${ }^{1}$ teachings which were at the basis of the doctrines of the Presbyterian and Reformed Churches. These teachings spread also among the French Huguenots, the Protestants of Netherlands and Scotland, and the Puritans of England. One of the main themes in their religious faith is "predestination" which means that man's destiny was determined by God. The Dutch who moved to South Africa believed firmly in the idea that they were chosen by God to accomplish a mission in this part of the world. Their settlement was regarded as a providential manifestation ${ }^{2}$.

Apparently, the belief of being chosen by God implied for the dutch settlers that the other races were destined to be under their domination. The preachers of these views found their justifications in the Old Testament which put emphasis on the fact that human beings were created different and, consequently, put in different scales, i.e. masters and servants. In 1889, the Dutch Reformed Church (D.R.C.) accepted separation as a principle, but refused to apply it in its internal functioning. This acceptance had given to the white South African rulers the moral support they needed to conduct their policies of segregation which crystallised into Apartheid system of government from 1948 onwards.

When the Union of South Africa was proclaimed on May 31, 1910, two main political parties emerged: the South African Party and the Unionist Party. While the former gained 66 seats in the Assembly and won the elections of 1910 under the leadership of General Luis Botha (1910-1924), the latter led by Leander Starr Jameson had 38 seats and formed the opposition. The first government was composed of 10 ministers: four English and six Afrikaners. Among the Afrikaners were J. C. Smuts and J. B. M. Hertzog who was put in charge of the native affairs.

The South African Party's policy was based on two main points. The first was the reconciliation between all whites (Dutch and English), and the second was the loyal cooperation with Great Britain. In 1911, the Minister of Native Affairs, Hertzog, proposed a bill that tended to restrict the areas of the bantou reserves and to prohibit property transactions between the whites and non-whites, but was defeated in parliament in December 1912. Following this, Prime Miniter Botha dismissed Hertzog because of his anti-British opinions and openly expressed racism, which provoked a schism in the South African Party. A group of members of the SAP broke away and founded a new party called the Nationalist Party (NP).

The priorities of PM Hertzog were to withdraw from Dominion status and entrench white supremacy in the country. In the elections of May 1933, Hertzog was obliged to rejoin Smuts to form a coalition because of social disturbances engendered by the world economic crises of 1929. The merger of the NP and the SAP in December 1934 gave birth to the United Party (UP) on the grounds of a compromise. In return for embracing Smut's ideas related to the status of South Africa within the Commonwealth, Hertzog was given a free hand

\footnotetext{
1 John Calvin (1509-1564) was a French Protestant theologian who rebelled against the Roman Catholic Church. He called for a simpler Christianity.

2 Malan wrote: «L'histoire des Afrikaners révèle une intention si déterminée et si précise qu'on est amené à penser qu'elle n'est pas le fait des hommes mais l'œuvre de Dieu. Nous avons le droit divin d'être Afrikaners. Notre histoire est l'œuvre d'art la plus forte qu'ait conçue le plus grand architecte des siècles.»; in: Charles Cadoux. L'Afrique du Sud. Paris: Librairie de Droit et de Jurisprudence, 1966, p. 189.
} 
regarding issues related to racial legislation ${ }^{3}$. However, a minority of extremists within the NP did not accept this fusion and accused Hertzog of treason to the ideals of the NP. In the same year, they broke away and founded the (Purified) Nationalists Party under the leadership of Dr. D. F. Malan ${ }^{4}$.

The unity of the NP and the SAP. did not last long. In the beginning of the second World War, the united Party split because of political divergence between Hertzog and Smuts about the party position vis-à-vis world war two ${ }^{5}$. While the former wanted neutrality, the latter backed Britain in the war against the Nazis. At last, the union of South Africa entered the war beside the Allies. The schism in the United Party gave way to the Purified Nationalist Party or the Nats ${ }^{6}$ to snatch the political leadership in the country, and eventually the implementation of the Apartheid system in 1948.

Apartheid is probably the only Afrikaans' word known to most people in the world. It simply means "separation of different ethnic groups in all aspects of life" in South Africa. The concept of Apartheid was produced by a group of intellectuals at the University of Stellenbocsh ${ }^{7}$. They founded an organisation known as the South African bureau of Racial Affairs (SABA) as a reaction to the Liberal Race Relations Institute (LRRI) of Johannesburg. The LRRI's members considered that there should be no racial discrimination in the law and in administration.

It is worth mentioning that several founding members of the SABRA became Prime ministers of South Africa, like Dr. Malan (1948-1954), and Dr. Verwoerd (1958-1966). Pr. Eiselen, who was Permanent Secretary of the Native Affairs Department, defined the meaning of Apartheid as follows:

By separation, I mean separating the heterogeneous groups from the population of this country into separate socio-economic units, inhabiting separate parts of the country, each enjoying in its own area full citizen rights, the greatest of which is the opportunity of developing such capabilities as its individual members may possess to their optimum capacity. ${ }^{8}$

Theoretically, this implies that Apartheid did not advocate segregation but separation of different ethnic groups ${ }^{9}$ in distinctive areas where each had full rights. The socio-economic and political development of each community depended on the endeavour and capacities of its people. Apartheid was not a simple continuation of the previous policies of segregation applied in South Africa but a radical and a coherent doctrine, which gradually evolved from 1948 onwards.

Apartheid was considered as the complete and suitable solution to the racial problem in the country. It was the keyword for 1948 electoral campaign of the Nationalist Party under the leadership of Malan. These elections were in favour of the NP who won 70 seats out of 153, and Malan became Prime Minister from 1948 to 1954. Once in power, the NP started dealing with the question of the relations between whites and non-whites, and the establishment of the Afrikanerdom. On Taking office, PM Malan declared:

Today, South Africa belongs to us (Afrikaners) once more. For the first time since Union, South Africa is our own. May God grant that it will remain our own. ${ }^{10}$

\footnotetext{
${ }^{3}$ Ibid., p. 106.

4 Malan was the Minister of Home Affairs in Hertzog's first Cabinet of 1924.

5 At the time Hertzog was the PM and Smuts his vice-PM.

6 After the split in the coalition government formed by the N.P. and the S.A.P., the Purified Nationalist Party was known as the Nationalist Party or the Nats.

7 Colin Legum. Africa, a Handbook of the Continent. New York: Praeger, 1967, p. 355.

8 John Hatch. History of Post-War Africa. New York: Praeger, 1965, p.88.

9 There were for recognised ethnic groups: The Whites, The Coloured, The Asians, and The Blacks or Bantous.

${ }^{10}$ Quoted by Colin Legum, op. cit., p. 344.
} 
Henceforward, a rigid and rigorous segregation was applied between the whites and non-whites. After Malan came Strijdohm (1954-1959), with the theory of Baaskap or "white masterdom". From 1959, Prime Minister Verwoerd (1959-1966) applied the concept of "separate development" or "vertical Apartheid". These modifications in the official terminology reveal the gradual consolidation of the doctrine in order to entrench the white domination over the other races in South Africa.

In the period between 1948 and 1969, the South African Parliament enacted laws that defined clearly the framework of the Apartheid policy. Racial legislation touched every aspect of social life. In 1949, the Prohibition of Mixed Marriages Act was passed to prohibit marriages between the whites and the non-whites. Then, in 1950, the Immortality Amendment Act was passed to ban sexual intercourse between the Europeans and the other ethnic groups.

After "physical contact" had been prohibited mainly between the whites and the non-whites, the population was categorised into three main ethnic groups according to the Population Registration Act of 1950: Whites, Coloured (people of mixed races and the Asians) and the Bantous. Complexion was the principal criterion that placed an individual in a certain ethnic group. Once the population in South Africa was classified into distinct ethnic groups, the government issued the Groups Areas Act of 1950, which was considered as the cornerstone of the Apartheid system since it allocated dwelling areas exclusively for each ethnic group. On that basis, the Bantu Authorities Act was enacted in 1951 to establish ethnic governments on the reserves known as "Homelands". Henceforward, the Africans were obliged to carry their "Reference Books" when moving from black areas to the white ones. In fact, it was like moving from one state to another.

In the economic fields, the government's main concern was to safeguard the privileges of the white workers and protect them from any competition from the part of the non-white workers. To reach this objective, the policy of "Job Reservation" was applied in all domains: factories, building sites, administration, etc. The Mines and Works Act of 1956 excluded Africans from other jobs than labouring in the mines. The Parliament passed the Factories, Machinery and Building Act of 1960 to prevent contact between white and non-white workers. The white and the non-white workers did not meet in places like canteens, rest rooms, dressing rooms, etc.

Through the enactment of these laws, the Apartheid regime entrenched the supremacy of the whites and tightened its grip on native and coloured populations in South Africa, and created tensions to which the national and international community did not remain indifferent.

\section{Internal Opponents to Apartheid in South Africa}

Reactions opposing the policies of segregation in South Africa were mainly provoked by intellectuals, politicians, churchmen, etc., from different ethnic groups. It would be a mistake to think that all the whites approved, to a certain extent, apartheid. It was thought that total apartheid was unworkable because it deprived the white population from cheap and abundant black labour force. However, the Nationalist Party, through its succeeding Prime Ministers, managed to make separation and exploitation practicable and profitable.

The opposition to Apartheid came also from the official institutions. The spreadhead of this opposition was the United Party, which rejected the policies of Apartheid but insisted on the maintaining of the white supremacy or leadership. The party advocated gradual economic integration of non-white ethnic groups and refused their participation in any social or political manifestations. The other political parties were not of big threat to the NP, but stressed on the recognition of the human rights of the non-whites. In this sense, the Liberal 
Party was founded in 1953 to work for a multiracial society where the rights and freedoms of all people should be respected without distinction of colour or race. In fact, the doctrines of the Liberal Party were greatly influenced and inspired by the Universal Declaration of Human Rights. However, neither the Europeans nor the other ethnic groups supported the Party ${ }^{11}$.

Protesting against the non-liberal policies of the United Party, a group of members broke away and founded the Progressive Party in 1959. The new Party also advocated the respect of human rights and the safeguard of the dignity of human beings. The Progressive Party opposed the policies of the Nationalist Party and demanded constitutional reforms to meet its objectives.

Non-white opposition to the policies of segregation in South Africa began before the establishment of the Union of South Africa. It started with the Natal Indian Congress, whose origins can be dated back to the first struggle of the Indian originated population, around 1894, to be recognised as an integral part of South African society. Mahatma Ghandi played an important role in shaping the party's policies and tactics of struggle, known as "passive resistance" and "Civil disobedience". In 1920, a new political organisation was created after the departure of Ghandi known as the South african Indian Congress (SAIC). The party turned to be actively militant from 1946 onwards.

But the most prominent opponent of Apartheid was the Africa national Congress (ANC) which was founded in 1912. At the beginning, the Party's policy was rather reformist and conciliatory before apartheid. After 1948, it became increasingly involved in militant activities. In 1959, the ANC undertook actions to destabilise the economy of South Africa through strikes like the "Stay-at-home" strike, which was launched on May 1, 1950. Two years later, the Party protested against the racial legislation through the "Defiance Campaign", which aimed to put an end to segregation in the country. However, the ANC split in 1959 and Robert Sobukwe founded the Pan-African Congress (PAC), which asked for concrete actions against the regime and repudiated the idea of alliances or cooperation either with the white moderates or the other non-white parties. Events took a sharp turn when the ANC announced a manifestation on March 31, 1960 against the "Pass Laws" 12 . Nevertheless, the PAC launched the manifestation eight days earlier. The situation worsened when the police of Sharpville fired on unarmed demonstrators, killing 67 and wounding nearly 200 people ${ }^{13}$. Four days later, the ANC and the PAC were disbanded.

The non-white opposition reached agreement and cohesion in 1955 when the People's Congress was founded by the main non-white political parties, trade unions, and white liberals. They met at the conference of Cliptown in Transvaal, and adopted the Freedom Charter as a platform for their common opposition to Apartheid. However, the opposition to Apartheid in South Africa was not totally efficient to the point to oblige the government to abandon its Apartheid policies. This opposition had however the merit of drawing the attention of the international community on the situation of the non-whites in South Africa.

\section{The Struggle Against Apartheid in the United Nations (1948-1969)}

International public opinion was unanimous in its opposition to South Africa's policies of Apartheid. The latter was described as "abhorrent" by Britain, as "toxic" by U.S.A, as "shameful" by U.S.S.R., as "hateful" by

\footnotetext{
11 Charles Cadoux, op. cit., p. 274.

12 The African workers were obligers to carry a pass valid for limited period to seek for a job in the whites' areas.

${ }^{13}$ Gwendolen Carter. The Republic of South Africa. Africa. Indiana University Press, edited by Philip M. Martin, 1984 , p. 341.
} 
India, as "cancer" by Algeria, and as "fundamentally immoral" by Japan ${ }^{14}$. Although there was overwhelming condemnation of the Apartheid system, there was no general agreement upon the means to be used to induce South Africa to change its policies. The purpose of the following section is to descript the early reactions and struggle of the international community within the United Nations against Apartheid from its establishment in 1948 to the 1960 s.

\section{Political and Diplomatic Reactions Against Apartheid (1948-1959)}

The end of the Second World War announced a new era in modern history where ideologies divided the world into two antagonistic blocs: the capitalist West led by the U.S.A. and the communist East under the leadership of the Soviet Union. In this context of tense relations, international and regional organisations such as the United Nations Organisation, the Organisation of African Unity and the Non-aligned Countries Organisation were founded, all created mainly to settle international and regional disputes, promote world peace, and ensure the respect of human rights.

The first country to oppose South Africa's apartheid system was India, which lodged a complaint to be treated by the first U.N. General Assembly in $1946^{15}$. By enacting the Asiatic Land Tenure Act of $1946^{16}$, the South African government violated the treaties ${ }^{17}$ that were signed by both countries concerning the treatment of the Indian originated population in South Africa. The Act limited the right of the Asians to buy or occupy a property without the consent of the Ministry of the Interior. India considered the Act as discriminatory and a flagrant infringement to Article 13 (1.b) of the U.N charter, which South Africa's PM Smuts participated in its elaboration and signing. In defending his country, Smuts denied any violation of the rights of the Asians in South Africa, and invoked Article 2, paragraph 7, of the U.N. charter; arguing that the matter was essentially within the domestic jurisdiction of South Africa.

Notwithstanding Smuts' arguments, the General Assembly decided in October 26, 1946 to include in its agenda the Indian complaint entitled Treatment of Indians in the Union of South Africa. The complaint was voted by 32 in favour and 15 against; and voted down the South African demand to withdraw India's complaint by a vote of 36 to none ${ }^{18}$. However, the G.A. of 1948 was unable to adopt any resolution on the Indian complaint for lack of a two-thirds majority.

India requested consideration of its complaint against South Africa for the second time in 1948 because of the application of apartheid. India considered apartheid as a serious threat to the solidarity and peace between world nations. As a response, the G.A. of 1949 adopted Resolution 265 (III) ${ }^{19}$ in which it invited India, South Africa and Pakistan to enter discussions at a round table conference. Preliminary discussion began in Cape Town in 1950 to explore the possible means and ways to settle the question. However, the Nationalist Party applied the Group Areas Act of 1950 and India decided to boycott the round table conferences as a protest.

India succeeded in passing Resolution $395(\mathrm{~V})^{20}$ in December 2, 1950, in which apartheid was described as a policy based on doctrines of racial discrimination. The G.A. of October 1952 included a discussion on

\footnotetext{
${ }^{14}$ Colin Legum, op. cit., p. 342.

15 The first General Assembly was held in London, and the UN Secretary General was Tryge Lie (1946-1952).

16 The Indians, the Pakistanis, and the Filipinos were considered as Asiatic.

17 Franck. L. Schoell. Les Tensions Raciales dans L'Union Sud Africaine et leur Incidences Internationales. Paris: Librairie Droz, 1956, p. 93.

18 Mary Benson. South Africa: The Struggle for a Birthright. London: Penguin Books, 1966, p. 112.

19 Published Documents of the UN, A/RES/256 (III), July12, 1949.

20 Published Documents of the UN, A/RES/395 (V), December 2, 1950.
} 
Apartheid in its agenda, based on a joint request of 13 Afro-Asiatic countries ${ }^{21}$. This initiative was intended to draw attention on the situation of non-whites in South Africa. Their request was based on Article 1 Paragraph 3, Article 55 paragraph $\mathrm{C}$, and Article 56; the principles of which were infringed by the application of apartheid laws.

In this regard, the G.A. of December 5, 1952 adopted Resolution 616 (VII) ${ }^{22}$ to establish a three members committee to consider the racial situation in South Africa. The committee was composed of Hernan Cruz of Chile, Ralph Binche of U.S.A and Jaime Tores Bodet of Mexico. In March 1953, Bunche and Tores were replaced by Henri Laugier of France and Dantes of Haiti. The last committee found it difficult to conduct its investigations since the South African government refused entry to its members. The committee managed to present its report based on legislative texts, newspaper articles and recent books, but far from eye witnessing the harsh conditions of the non-whites in South Africa.

The difficulty found by India to incriminate Apartheid in the United Nations, obliged it to look for other battle grounds than the United Nations, and gather as many countries as possible to stand against South Africa. In this instance, the Bandoeng conference held on April 18, 1955 was the starting point of an Afro-Asiatic offensive against Apartheid. Twenty nine African and Asian countries attended the conference. Two South Africans were invited to participate in the conference as observers, namely the African Moses Kotane and the Indian originated I. A. Cashaa. They were given the opportunity to expose the situation of racial discrimination in South Africa to the participants. Therefore, the conference adopted a resolution, amongst others, in which South Africa was openly named and condemned. Henceforward, South Africa became a soft target of criticism.

It is only in the Pan-African conference of Accra (Ghana) in 1958 that a resolution was adopted in which member states decided to break off diplomatic and economic relations with South Africa. Adding to that, in the Afro-Asiatic conference of Conakry (Guinnea) on April 1960, opposition organisations of the Basutoland and South West Africa were invited to attend the conference as expression of solidarity.

As the General Assembly continued to raise the question of Apartheid in South Africa, the Minister of Foreign Affairs Eric Louw accused the G.A. of interfering in domestic affairs, and menaced the U.N. in November 27, 1956 that South Africa would maintain only token representation at the U.N meetings. It is to be noted that the Resolutions adopted between 1957 and 1959 expressed only deep regret and concern that South Africa did not respond positively to the appeals of the international community. This attitude of moral disapproval did not worry seriously the South African government, which pursued its racial policies.

It was the events of Sharpville that changed the way the United Nations and the whole international community treated apartheid in South Africa. Four days after the massacre, the representatives of 29 Afro-Asian member states of the U.N. requested an urgent meeting of the Security Council to consider the "Sharpville Events". On April 1, 1960, the S.C. adopted its first resolution on the question under the number of $134^{23}$, in which it deplored the policies and actions of the South African government which were responsible for the loss of so many lives, and called the government to abandon Apartheid policies with a vote of 9 in favour and 2 abstentions (United Kingdom and France).

\footnotetext{
${ }^{21}$ The Afro-Asiatic countries were Saudi Arabia, Egypt, India, Pakistan, Philippine, Iran, Iraq, Lebanon, Burma, Afghanistan, Syria, Yemen, and Indonesia.

${ }^{22}$ Published Document of the UN, A/RES/616 (VII), December 5, 1952.

23 Published Document of the UN, A/RES/134, April 1, 1960.
} 
The events of Sharpville put a different complexion on the question of racial discrimination in South Africa. During the conference of Commonwealth Prime Ministers, South Africa was openly blamed. The new position of the Commonwealth member states vis-a-vis apartheid policies had been one of the main reasons that pushed P. M. Verwoed (1958-1966) to announce the withdrawal of South Africa from the Commonwealth, and to proclaim the birth of the Republic of South Africa on May 31, 1961. Presumably, the change in the official position of the United Kingdom towards the question of Apartheid was at the basis of this proclamation. In the previous U.N. resolutions, the U.K. adopted a position of non involvement in the domestic affairs of South Africa. But on April 1961, the U.K. voted for resolution 1598 (XV) ${ }^{24}$, which condemned apartheid as "reprehensible and repugnant to human dignity". This resolution was voted by 96 to 1 , with no abstentions. Only Portugal voted against ${ }^{25}$.

From 1961 onwards, it was felt that no other decisions condemning what was happening in South Africa should be adopted, only regrets were expressed by the international community. The G.A. of November 1962 left to the member states to take initiatives for separate or joint specific measures to induce South Africa to abandon Apartheid. These measures included breaking off diplomatic ties, trade and transport relations. A special committee $^{26}$ was appointed to follow the development of the situation in South Africa and report to the G.A and the Security Council. By October 1963, 27 G.A. and 2 S.C. resolutions were passed to condemn apartheid. The year 1963 marked the end of 17 years of verbal condemnations and the beginning of concerted actions against South Africa.

Despite the UN resolutions, the South African government continued the repression of its opponents. In June 1963, the police arrested underground activists at Rivonia, a suburb of Johannesburg, mainly from the African National Congress and other tendencies, including some leading militants like Nelson Mandela, Mbeki, Sisulu, Goldberg, Katharada, Mhalba, Mlangeni, and Motsoaledi. They were all sentenced to life imprisonment. As a reaction against what was known as the "Rivonia Trial", the G.A. of October 11, 1963 adopted resolution 1881 (XVII) $^{27}$ in which the South African government was requested to abandon the trial and to stop repression of people opposing Apartheid. The vote was unanimous 106 to 1. Only South Africa voted against.

It is worth noticing that the deterioration of the relations between South Africa and the International Community reached its climax in November 12, 1974, when the President of the General Assembly Abdelaziz Bouteflika $^{28}$ suspended South Africa from participating in the remainder of Assembly sessions for that year. It did not take long to the South African government to react. In the following day, it called back its U.N Ambassador and freezed its $\$ 1$ million annual contribution to the organisation.

The African bloc helped by Asian and Arab states, succeeded in isolating the South African regime by denying it full representation in the various specialised U.N. institutions and agencies. Tactics of humiliating and irritating the regime were well conducted since South Africa withdrew voluntarily from the Food and Agriculture Organisation (F.A.O.) and the International Labour Organisation (I.L.O.) in 1963 and 1964, respectively. Nevertheless, those tactics failed to exclude South Africa from organisations like the International

\footnotetext{
${ }^{24}$ Published Document of the UN, A/RES/1598 (XV), April, 1961.

25 Portugal's position was due to its repressive colonial policy in Angola that was criticised by most countries within the U.N., except South Africa and Spain. In 1961, Portugal did not allow a U.N sub-committee to investigate on the situation in Angola.

26 This committee started on April 2, 1963. It was composed of 11 members. There were 5 African states (Algeria, Ghana, Guinea, Nigeria, and Somalia), 3 Asiatic states (Malaysia, Philippine, and Nepal), 2 Latin America states (Costa Rica and Haiti) and 1 European state (Hungary).

${ }^{27}$ Published Document of the UN, A/RES/1881 (XVIII), October 11, 1963.

28 Abdelaziz Bouteflika was at the time the Minister of Foreign Affairs of Algeria.
} 
Atomic Energy Agency (I.A.E.A.) because of its important production of Uranium. Accordingly, the activities of the O.A.U. became a serious threat to the South African commerce and transport. From 1963, Pretoria had practically no relations with the African states. The unified front which the African countries formed within the U.N. pushed the Security Council to stand against the Apartheid regime. The General Assembly of October 26, 1966 proclaimed the date of March 21 as "the international day for the elimination of racial discrimination" in resolution 2142, A $(\mathrm{XXI})^{29}$, and in December 2, 1968, it requested all states and organisations to suspend cultural, educational, sporting, or other activities with the racist regime and organisation that practice apartheid in South Africa.

Worldwide political and diplomatic campaigns against South Africa's discriminatory policies proved to be relatively efficient. The political and diplomatic actions, mainly conducted by the Third World Countries, contributed enormously to the isolation of the Apartheid regime. It should be said that the developed countries did not get involved efficiently in the struggle against Apartheid since the Security Council hadn't passed enough resolutions to right the wrongs done in South Africa. This attitude is not only caused by the peculiar nature of the "Domestic Colonisation" in South Africa, but by the fact that the racist regime had the industrial and economic wealth and the natural resources of the country at its disposal ${ }^{30}$.

\section{The United Nations' Economic Sanctions Against South Africa}

After the Second World War, most investments of international firms in Africa were primarily in the fields of extraction, the shipping out of raw materials and partial processing ${ }^{31}$. While the relatively limited range of investments was more profitable to the foreign companies, it had little impact on the overall growth of the African countries. The largest foreign investments were oriented and sought in those countries where political stability was provided to ensure commercial profits. The countries where the liberations movements made their way were generally avoided. In this case, South Africa was one of the most favourable countries to invest in, which helped greatly in the development of its economy ${ }^{32}$.

Before the settlement of the Dutch in South Africa, the economy of the local population was essentially based on either agriculture or hunting. However, things changed with the arrival of the Europeans who introduced far more developed techniques in most domains. The discovery of diamonds and gold respectively in 1867 and in 1886, marked the starting point for a strong South African economy that gradually moved the country from being agricultural to an industrialised one. Such industrialisation depended greatly on external capitals mainly from Great Britain and the U.S.A. ${ }^{33}$. In addition to diamonds and gold, the country was rich of other important minerals like Uranium, Chrome, Vanadium, Manganese, etc., which attracted foreign investments and the interest of the industrialised countries. During the 1960's, South Africa had 80\% of the world's known reserves of Chrome and Manganese and dominated the international market of Vanadium, Antimony, and gold ${ }^{34}$. In return for supplying the U.S.A with Uranium from 1953 onwards, South Africa received technological help to develop its nuclear research programmes. Promoting a nuclear, mining and

\footnotetext{
${ }^{29}$ Published Document of the UN, A/RES/2142 (XXI), October 26, 1966.

${ }^{30}$ Gus Liebenow. Africa's Place in the Sun: The Expanding Arena of International Politics. Africa. Indiana University Press, Philip M. Martin ed., 1986, p. 360.

31 Reginald H. Green and ANN Siedman. Unity and Poverty: The Economics of Pan-Africanism. U.S.A.: Penguin Books, 1968, p. 99.

32 Ibid.

${ }^{33}$ Grant S. McCellan. The Key: South Africa's Economy. Southern Africa, the Reference Shelf. New York: The Wilson Company, 1979, Vol. 51, No. 3, p. 120.

${ }^{34}$ Victor T. Levine. South Africa in the World. The Africans: A Reader. New York: Praeger, 1996, pp. 248-249.
} 
processing industries in the country was for U.S.A. a strategic policy because of the post world war nuclear arms race with the U.S.S.R. Deputy Under-Secretary of State during President Carter's administration, Joseph Nye Jr. said:

South Africa became an important supplier of Uranium to the U.S.A beginning in 1953. These shipments continued until early 1960's (...) We entered agreement for nuclear cooperation with South Africa on July 1958 (...) The initial type of cooperation was in the area of research, but eventually cooperation in nuclear power was envisioned from the beginning $^{35}$.

Therefore, the only measures that were susceptible to affect the Apartheid regime were of economic nature. Although the economic sanctions against South Africa had been adopted easily from 1962 onwards, they didn't find their way to effective application until $1966^{36}$. This was due to the fact that the Security Council passed recommendations and not decisions against South Africa. The first concrete economic sanctions against South Africa was on August 7, 1963, when the Security Council adopted Resolution $181^{37}$ calling upon all states to cease the sale of arms, ammunition and military vehicles to South Africa. Two months later, 43 states announced that they placed the trade in arms and ammunition with South Africa under embargo. However, the U.S.A., the U.K., and France specified that the embargo should be on repressive arms not on the defensive ones, and that the already signed treaties with the South African government had to be honoured. The Embargo on trade as a whole did not find general acceptance by some developed countries like Japan, the Federal Republic of Germany, the U.K., and the U.S.A. It was advocated that such embargo would not only be harmful and prejudicial to these countries, but also to the black majority that needed help.

It was clear that the question whether to invest or not in South Africa was rather for ethical principles ${ }^{38}$. The industrialised countries whose economic systems were based on expanding commercial relations were prepared to deal with the devil as long as mutual benefits were the outcome. It was argued that these investments should not be stopped but encouraged, because the process of industrialisation would benefit the South African economy as a whole, and thereby, helping the non-whites to surpass their miserable conditions. Presumably, this view was that of the multinational firms and countries which had strong economic interests in South Africa. Although Apartheid was openly condemned, it was found that the most belligerent opponents of the system maintained profitable economic relations with it. It was estimated that some 41 African countries established commercial exchanges directly with South Africa or through third parties ${ }^{39}$.

Overall, the economic sanctions against South Africa during the 1960's were ineffective because of the country's strong economy. In the period between 1948 and 1969, South Africa witnessed a steady economic growth $^{40}$ which helped the apartheid regime to develop as an integral part of the Western global economic system and, eventually, to be protected from any coercive measures against it.

\section{References}

Benson, M. (1966). The struggle for a birthright. London: Penguin Books.

\footnotetext{
${ }^{35}$ Quoted by Robert A. Manning and Stephen Thalbot. Carter's Nuclear Deal with Africa. Southern Africa: The Reference Shelf. New York: The Wilson Company, 1979, Vol. 51, No. 3, p. 220.

36 Charles Cadoux, op. cit., p. 313.

37 Published Document of the UN, A/RES/181, August 7, 1963.

38 Adam Herirbert. Outside Influence on South Africa: Afrikanerdom in Disarray. The Journal of Modern African Studies, Cambridge University Press, June 1983, Vol. 21, No. 2, p. 360.

39 Victor T. Levine, op. cit., p. 249.

${ }^{40}$ Charles Cadoux, op. cit., p. 316.
} 
Cadoux, C. (1966). L'Afrique du Sud. Paris: Librairie Générale de Droit et Jurisprudence.

Carter, G. M. (1986). The Republic of South Africa. In Philip M. M. (Ed.), Africa (pp. 341-359). Indiana University Press.

Green, R. H., \& Siedman, A. (1968). Unity and poverty, the economics of pan-Africanism. Baltimore: Penguin African Library.

Grant, S. McCellan. (1979). The key: South Africa's economy. Southern Africa, the Reference Shelf, 51(3), 120-134. New York:

The Wilson Company.

Hatch, John. (1965). A history of post-war Africa. New York: Praeger.

Heribert, Adam. (1983). Outside influence on South Africa: Afrkanerdom in disarray. The Journal of Modern African Studies, 21(2), 1235-1251. Cambridge University Press.

Legum, C. (1967). Africa; a handbook to the continent. 4th ed. New York: Praeger.

Liebnow, G. (1986). Africa's Place in the Sun: The Expanding Arena of International Politics. In Philip M. M. (Ed.), Africa (pp. 360-379). Indiana University Press.

Levine, V. T. (1996). South Africa in the world. The Africans: A reader (pp. 248-249). New York: Praeger.

Manning, R. A., \& Thalbot, S. (1979). Carter's Nuclear Deal with Africa. Southern Africa, the Reference Shelf, 51. New York: The Wilson Company.

Published Documents of the U.N., General Assembly Resolutions, www.un.org/

Published Documents of the U.N., Security Council Resolutions. www.un.org/

Schoell, F. (1956). Les Tensions Raciales dans L'Union Sud Africaine et leur Incidences Internationales. Paris: Librairie Droz. 